\title{
Cane pruning on Chardonnay grapevine in the high-altitude regions of Southern Brazil
}

José Luiz Marcon Filho ${ }^{\text {a }}$, Ricardo Allebrandt, Douglas André Würz, Betina Pereira de Bem, Tiago Afonso de Macedo, Aike Anneliese Kretzschmar, and Leo Rufato

Santa Catarina State University (UDESC), College of Agriculture and Life Science, Av. Luiz de Camões, 2090, CEP 88520-000, Lages, SC, Brazil

\begin{abstract}
High-altitude regions of southern Brazil, located above $900 \mathrm{~m}$ above sea level, the cordon training with spur pruning is widely used because of easier application. In these regions, Chardonnay wine grape shows potential to produce quality wines, however, in commercial vineyards, the training system used has not provided productivities that makes economically viable the cultivation of this variety. Given this, the present study aimed to evaluate the effect of different cane-pruning systems on the vegetative, productive and enological potential of Chardonnay grapevines grown in the high-altitude region of Southern Brazil. The experiment was conducted in a commercial Chardonnay vineyard, located in São Joaquim - Santa Catarina State ( $28^{\circ} 17^{\prime} 39$ 'S and $49^{\circ} 55^{\prime}$ 56" W, to $1230 \mathrm{~m}$ a.s.l) during 2015 and 2016 vintages. Chardonnay vines (grafted on 1103 Paulsen) were planted in 2010 , with a $3.0 \mathrm{~m}$ (row) $\times 1.0 \mathrm{~m}$ (vine) spacing. The treatments consisted of different cane-pruning systems: Cordon spur-pruning (control); Sylvoz; Cazenave; Capovolto; single Guyot and double Guyot. Pruning was performed in August of each year when the buds were in the green tip developmental stage. Data was analyzed by Scott Knott test $(p<0.05)$ following a randomized block design with four replicates, each consisting of 12 vines per plot. We observed higher yield in the Cazenave and double Guyot training system with three and two more tons of grapes than spur-pruning respectively. The bud fertility was higher in plants trained in double Guyot. Vines spur-pruned showed higher relation of leaf area: production, with values above $100 \mathrm{~cm}^{2} \mathrm{~g}^{-1}$ grape at 2016 vintage. Commercial maturity of grapes (soluble solids, acidity and polyphenols) did not differ among training systems studied. The results suggest that cane-pruning systems could be an alternative to increase production efficiency of Chardonnay in highaltitude region of southern Brazil.
\end{abstract}

\section{Introduction}

Highland regions of Santa Catarina State, Brazil, have been acquiring great importance due to the high potential for wine production from Vitis vinifera L. cultivars [1-3]. Located between latitudes $26^{\circ}$ and $28^{\circ} \mathrm{S}$ and altitudes between $950 \mathrm{~m}$ and $1400 \mathrm{~m}$ a.s.l. the knowledge and characterization of this region shows potential to produce quality wines, but due to highlands of Santa Catarina State are being in an emergent wine grown region fundamental investigations into vineyard practices are necessary [4].

Training system is one of the factors in plant management that permits the grape grower to establish a particular training system and manipulate vine yield. It permits the selection of bearing wood (spurs and canes) and thereby influences the location and development of the canopy [5]. Training can modify the vine microclimate, altering the yield [6] and health of the plant [7], the grape maturation $[8,9]$ as well as pruning and harvesting costs [10].

Chardonnay is one of the oldest and most widely distributed wine grape cultivars and is of commercial importance for the world's wine-producing nations.

\footnotetext{
${ }^{a}$ Corresponding author: marconfilho_j1@yahoo.com.br
}

It is very versatile and can adapt to different climates and soils [11]. This cultivar also have been shown potential to produce quality wines in the southern Brazilian highlands [3].

Wine grape production in the high-altitude South of Brazil regions is based on the vertical shoot position (VSP) training system with cordon-spur pruning [4]; however, due the lower buds of Chardonnay vines are generally sterile [12], the training system used has not provided productivities that makes economically viable the cultivation of this variety in commercial vineyards. Furthermore, Chardonnay berry clusters are small and it genetically predisposed to a low percentage fruit set, particularly when climatic conditions are adverse [12]. Therefore, it is necessary to change pruning to enhance vine capacity and to retain extra buds. In this way, cane pruning can be more suitable for Chardonnay than spurpruning.

To improve our understanding about vineyard practices, the present study aims to investigate the effect of different cane-pruning systems on the vegetativeproductive development and enological potential of Chardonnay grapevines in order to guide appropriate management for white winemaking in regions $900 \mathrm{~m}$ a.s.l. of Southern Brazil. 


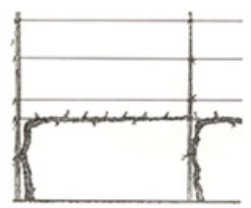

A

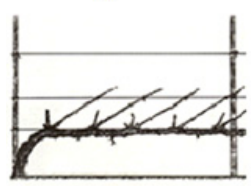

D
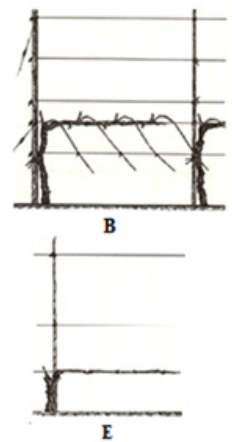
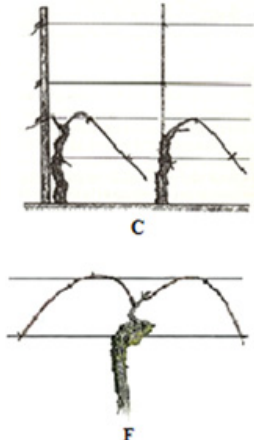

Figure 1. Training systems performed on Chardonnay grapevine in the high-altitude regions of southern Brazil. A - Cordon spurpruning (control); B - Sylvoz; C - Capovolto; D - Cazenave; E - Single Guyot and F - Double Guyot.

Table 1. Number of buds per vine remained after pruning performing on the Chardonnay in the high-altitude regions of southern Brazil. Vintages 2015 and 2016.

\begin{tabular}{|c|c|c|}
\hline \multirow{2}{*}{ Training System } & \multicolumn{2}{|c|}{ Buds per vine } \\
\cline { 2 - 3 } & $\mathbf{2 0 1 5}$ & $\mathbf{2 0 1 6}$ \\
\hline Cordon spur-pruning & $28 \pm 5.7$ & $24 \pm 3.0$ \\
\hline Sylvoz & $50 \pm 13.5$ & $45 \pm 7.3$ \\
\hline Cazenave & $53 \pm 12.6$ & $36 \pm 7.3$ \\
\hline Capovolto & $15 \pm 2.7$ & $15 \pm 2.6$ \\
\hline Single Guyot & $14 \pm 3.1$ & $14 \pm 1.7$ \\
\hline Double Guyot & $31 \pm 6.1$ & $28 \pm 4.2$ \\
\hline
\end{tabular}

Data are the mean $\pm S D$.

\section{Materials and methods}

The experiment was undertaken in a commercial Vitis vinifera L. cv. Chardonnay vineyard located in the highlands of Santa Catarina State, south of Brazil $\left(28^{\circ} 14^{\prime} \mathrm{S}, 49^{\circ} 58^{\prime} \mathrm{W}, 1230 \mathrm{~m}\right.$ a.s.1.) during the 2015 and 2016 vintages. Chardonnay vines (grafted on '1103 Paulsen') were planted in 2010 in a northwest to southeast row orientation, with a $3.0 \mathrm{~m}$ (row) $\times 1.0 \mathrm{~m}$ (vine) spacing. Vines were trained on a vertical shoot position.

The treatments consisted of different cane-pruning systems: A - Cordon spur-pruning (control). B - Sylvoz (four 7-bud canes arched down). C - Capovolto (one 10 to 15-bud cane arched down). D - Cazenave (four 7-bud canes arched $45^{\circ}$ up). E - Single Guyot (one 10 to 15-bud cane arched horizontally to the soil surface) and F - Double Guyot (two 10 to 15-bud cane arched) (Fig. 1). The number of bud per vine remained after pruning performing on the Chardonnay can be observed at Table 1 .

Pruning was performed in August of each year when buds were in the green tip developmental stage. At all canepruning system one renewal spur were left to each cane.

Harvest started according to the winery standards. During harvest the number of cluster and branch per vine and production $\left(\mathrm{kg}\right.$ vine $\left.^{-1}\right)$ from 8 plants per treatment were obtained. Leaf area $\left(\mathrm{m}^{2}\right.$ vine $\left.^{-1}\right)$ was calculated from measuring of total leaf area per branch $(n=10)$ and number of branch per vine. Based on these data was estimated leaf area/fruit (LA/F $\left.-\mathrm{cm}_{2} \mathrm{~g}^{-1}\right)$, yield $\left(\mathrm{t} \mathrm{ha}{ }^{-1}\right.$ ) and the bud fertility (clusters/ shoot per vine).

At harvest, 100 berries were randomly collected per plot/treatment from different portions of the vine and both sides of the rows. Samples were immediately submitted
Table 2. Productivity parameters of Chardonnay grapevine under the effect of different training system in the high-altitude regions of southern Brazil. Vintages 2015 and 2016.

\begin{tabular}{|c|c|c|c|c|c|c|}
\hline \multirow[t]{2}{*}{ Training } & \multicolumn{2}{|c|}{$\begin{array}{l}\text { Cluster per } \\
\text { vine }\end{array}$} & \multicolumn{2}{|c|}{$\begin{array}{c}\text { Production } \\
\left(\text { kg vine }^{-1}\right)\end{array}$} & \multicolumn{2}{|c|}{$\begin{array}{l}\text { Yield } \\
\left(\mathbf{t} \mathbf{h a}^{-1}\right)\end{array}$} \\
\hline & 2015 & 2016 & 2015 & 2016 & 2015 & 2016 \\
\hline Spur-pruning & $22 \mathrm{~b}$ & $5 \mathrm{c}$ & $2.49 \mathrm{~b}$ & $0.33 \mathrm{c}$ & $8.3 \mathrm{~b}$ & $1.1 \mathrm{c}$ \\
\hline Sylvoz & $33 \mathrm{a}$ & $10 \mathrm{a}$ & $2.58 \mathrm{~b}$ & $0.88 \mathrm{a}$ & $8.6 \mathrm{~b}$ & $2.9 \mathrm{a}$ \\
\hline Cazenave & $29 a$ & $9 \mathrm{a}$ & $3.32 \mathrm{a}$ & $0.94 \mathrm{a}$ & $11.1 \mathrm{a}$ & $3.1 \mathrm{a}$ \\
\hline Capovolto & $21 \mathrm{~b}$ & $3 \mathrm{~d}$ & $1.95 \mathrm{c}$ & $0.23 \mathrm{c}$ & $6.5 \mathrm{c}$ & $0.8 \mathrm{c}$ \\
\hline Single Guyot & $14 \mathrm{~b}$ & $3 \mathrm{~d}$ & $1.67 \mathrm{c}$ & $0.21 \mathrm{c}$ & $5.6 \mathrm{c}$ & $0.7 \mathrm{c}$ \\
\hline Double Guyot & $26 \mathrm{a}$ & $7 \mathrm{~b}$ & $2.96 \mathrm{a}$ & $0.68 \mathrm{~b}$ & $9.8 \mathrm{a}$ & $2.3 \mathrm{~b}$ \\
\hline C.V (\%) & 23.15 & 13.45 & 10.37 & 15.74 & 10.37 & 15.74 \\
\hline
\end{tabular}

*Means followed by different letters in the same column differ by Skott Knott test $(\mathrm{p}<0.05)$.

to the following analysis: a. soluble solids ( ${ }^{\circ}$ Brix); b. titratable acidity (meq L $\left.{ }^{-1}\right)$; c. $\mathrm{pH}$ and d. total polyphenols $\left(\mathrm{mg} \mathrm{L}^{-1}\right)$. These analyses were determined by protocols of OIV [13].

For polyphenol extraction $25 \mathrm{~g}$ of skins were weighted, homogenized in $10 \mathrm{ml}$ of methanol (1:1), macerated for 24 hours at $30 \pm 0.5^{\circ} \mathrm{C}$ and then washed with $2.5 \mathrm{ml}$ methanol (1:1). A second extraction with the remains of the skins was made with the same methanol volume as well as the time at $0 \pm 0.5^{\circ} \mathrm{C}$. Both extracts were separated, homogenized and filtered through Whatman 01 filter paper. Total polyphenols concentration was determined by the spectrophotometry method described by Singleton and Rossi [14], using the Folin-Ciocalteu reagent, with absorbance in $760 \mathrm{~nm}$ wavelength. Phenolic content was determined using a gallic acid calibration curve.

The experimental design was a randomized blocks with four blocks and 12 vines per plot. Data was analyzed by the $\mathrm{F}$ test and Skott Knott's multiple range tests $(\mathrm{p}<0,05)$.

\section{Results and discussion}

Training systems strongly modified productivity parameters of Chardonnay grapevine (Table 2). Greatest production per plant was obtained from Cazenave, followed by double Guyot and Sylvoz. We observed on the Cazenave and double Guyot three and two more tons of grapes per hectare than spur-pruning at both vintages, while Sylvoz was more productive than spurpruning only at 2016 harvest. Sylvoz and Cazenave tend to produce higher production due greater number of buds retained per vine in comparison to cordon spur-pruning. However, the number of bud per vine between double Guyot and spur-pruning was similar (Table 1). Chardonnay grapevines have a tendency to show lower fertility at basally positioned buds [12]. This can be explain higher productivity at double Guyot given that in this training system more apically positioned bud are retained. The poor performance of single Guyot and Capovolto may be attributed to have lower buds per vine, resulting in a lower yield at both vintages.

Bud fertility and relation of leaf area/fruit were affected by training system (Table 3 ). The bud fertility was higher in plants trained in double Guyot at both vintages. While vines in the Cazenave $\left(9 \mathrm{~cm}^{2} \mathrm{~g}^{-1}\right)$ and double Guyot $\left(8 \mathrm{~cm}^{2} \mathrm{~g}^{-1}\right)$ proved to be more equilibrated: a value from 7 to $14 \mathrm{~cm}^{2} \mathrm{~g}^{-1}$ is reported by the literature 
Table 3. Bud fertility and relation leaf area/fruit of Chardonnay grapevine under the effect of different training system in the highaltitude regions of southern Brazil. Vintages 2015 and 2016.

\begin{tabular}{|c|c|c|c|c|}
\hline \multirow{2}{*}{ Training } & \multicolumn{2}{|c|}{$\begin{array}{c}\text { Bud Fertility } \\
\text { (Clusters per shoot })\end{array}$} & \multicolumn{2}{c|}{$\begin{array}{c}\text { Leaf area/fruit } \\
\left(\mathbf{c m}^{2} \mathbf{g}^{-\mathbf{1}}\right)\end{array}$} \\
\cline { 2 - 5 } & $\mathbf{2 0 1 5}$ & $\mathbf{2 0 1 6}$ & $\mathbf{2 0 1 5}$ & $\mathbf{2 0 1 6}$ \\
\hline Spur-pruning & $1.3 \_\mathrm{b}$ & $0.5 \mathrm{~d}$ & $20 \mathrm{~b}$ & $128 \mathrm{a}$ \\
\hline Sylvoz & $1.3 \mathrm{~b}$ & $0.9 \mathrm{~b}$ & $23 \mathrm{a}$ & $39 \mathrm{c}$ \\
\hline Cazenave & $1.3 \mathrm{~b}$ & $0.8 \mathrm{c}$ & $9 \mathrm{~d}$ & $44 \mathrm{c}$ \\
\hline Capovolto & $1.6 \mathrm{a}$ & $0.7 \mathrm{c}$ & $14 \mathrm{~b}$ & $81 \mathrm{~b}$ \\
\hline Single Guyot & $1.3 \mathrm{~b}$ & $0.8 \mathrm{c}$ & $16 \mathrm{~b}$ & $75 \mathrm{~b}$ \\
\hline Double Guyot & $1.6 \mathrm{a}$ & $1.1 \mathrm{a}$ & $8 \mathrm{~d}$ & $29 \mathrm{c}$ \\
\hline C.V (\%) & 9.02 & 12.12 & 8.02 & 27.12 \\
\hline
\end{tabular}

* Means followed by different letters in the same column differ by Skott Knott test $(\mathrm{p}<0.05)$.

Table 4. Chemical parameters of Chardonnay grapes under the effect of different training system in the high-altitude regions of southern Brazil: Vintages 2015 and 2016.

\begin{tabular}{|c|c|c|c|c|c|c|}
\hline \multirow{2}{*}{ Training } & \multicolumn{2}{|c|}{$\begin{array}{c}\text { Soluble } \\
\text { Solids }\left({ }^{\circ} \text { Brix }\right)\end{array}$} & \multicolumn{2}{c|}{$\begin{array}{c}\text { Acidity } \\
\left(\text { meq }^{-1}\right)\end{array}$} & \multicolumn{2}{|c|}{ pH } \\
\cline { 2 - 7 } & $\mathbf{2 0 1 5}$ & $\mathbf{2 0 1 6}$ & $\mathbf{2 0 1 5}$ & $\mathbf{2 0 1 6}$ & $\mathbf{2 0 1 5}$ & $\mathbf{2 0 1 6}$ \\
\hline Spur-pruning & $20.3 \mathrm{a}$ & $17.5 \mathrm{a}$ & $82.3 \mathrm{a}$ & $153.8 \mathrm{a}$ & $3.26 \mathrm{~b}$ & $2.90 \mathrm{a}$ \\
\hline Sylvoz & $20.3 \mathrm{a}$ & $17.7 \mathrm{a}$ & $76.9 \mathrm{a}$ & $137.7 \mathrm{a}$ & $3.31 \mathrm{a}$ & $2.91 \mathrm{a}$ \\
\hline Cazenave & $20.2 \mathrm{a}$ & $17.6 \mathrm{a}$ & $78.5 \mathrm{a}$ & $146.1 \mathrm{a}$ & $3.26 \mathrm{~b}$ & $2.90 \mathrm{a}$ \\
\hline Capovolto & $19.9 \mathrm{a}$ & $18.3 \mathrm{a}$ & $79.5 \mathrm{a}$ & $141.5 \mathrm{a}$ & $3.29 \mathrm{a}$ & $2.93 \mathrm{a}$ \\
\hline Single Guyot & $19.1 \mathrm{a}$ & $18.4 \mathrm{a}$ & $79.7 \mathrm{a}$ & $137.7 \mathrm{a}$ & $3.25 \mathrm{~b}$ & $2.94 \mathrm{a}$ \\
\hline Double Guyot & $19.8 \mathrm{a}$ & $17.8 \mathrm{a}$ & $78.5 \mathrm{a}$ & $131.6 \mathrm{a}$ & $3.27 \mathrm{~b}$ & $2.90 \mathrm{a}$ \\
\hline C.V $(\%)$ & 3.77 & 3.70 & 5.76 & 7.89 & 0.68 & 1.09 \\
\hline
\end{tabular}

*Means followed by different letters in the same column differ by Skott Knott test $(\mathrm{p}<0.05)$.

as acceptable $[5,15]$. We observed values higher than the ideal range at 2016 vintage for all training system. However, vines spur-pruned showed much higher relation of leaf area: production, with values above $100 \mathrm{~cm}^{2} \mathrm{~g}^{-1}$. On September 2015, the vineyard studied had shoots damaged by a radiation frost. Consequently, the number of cluster and production per vine was profoundly affected resulting unbalance vines. We observed vines trained on Sylvoz, Cazenave and double Guyot less damage, due some buds had not sprouted when frost occurred. Thus, training systems that are retained more buds per vine could be a better option in years with late frost because greater recoverability and improve vines with better balance.

The training systems affected yield but showed no impact on must composition (sugars, acidity, $\mathrm{pH}$ and phenolics) of Chardonnay grapevine at both vintages (Tables 4 and 5). In a trial comparing Pinot Noir wine grape among single, double Guyot and spurred cordon training system the authors did not detect difference for the same parameters under northeastern Italy conditions [6]. To another experiments with Seyval Blanc and Barbera grapevines the chemical constituents of the must and wine showed little influence of training system studied $[16,17]$. Depending on the environment and with the appropriate training system, yield can be increased with no detrimental impact on fruit quality $[15,18]$.

Despite the broad variability caused by frost of 2016 vintage, Sylvoz, Cazenave and double Guyot performed quite similarly in total cropping potential and final grape composition. However, the choice of training
Table 5. Total polyphenol of Chardonnay grapes under the effect of different pruning system in the high-altitude regions of southern Brazil at 2015 vintage.

\begin{tabular}{|c|c|}
\hline Training & Total polyphenol $\left(\mathbf{m g ~ L}^{-\mathbf{1}}\right)$ \\
\hline Spur-pruning & $713.6 \mathrm{a}$ \\
\hline Sylvoz & $723.2 \mathrm{a}$ \\
\hline Cazenave & $758.0 \mathrm{a}$ \\
\hline Capovolto & $725.2 \mathrm{a}$ \\
\hline Single Guyot & $754.2 \mathrm{a}$ \\
\hline Double Guyot & $700.9 \mathrm{a}$ \\
\hline C.V $(\%)$ & 9.16 \\
\hline
\end{tabular}

* Means followed by different letters in the same column differ by Skott Knott test $(\mathrm{p}<0.05)$.

system should primarily be based on establishment and management costs, besides upon evaluation of viticulture aspects, mainly ease of canopy management [16,17]. To condition of high-altitude region of southern Brazilian highlands the fact of shoots arched down in Sylvoz training system make it more prone to the effects of frost and the soil moisture. So, an overview the Cazenave and double Guyot training system could be a better option.

The results from this study show Chardonnay in cane pruning resulted in improved vine balance and yield as well as it having similar grape maturation when compared to the spur-pruning. Therefore, future research must focus on evaluating the influence of training system on other grape metabolites, mainly aroma compounds as well as incidence and severity of disease, in order to improve the vineyard practices to achieve greater quality wine in the southern Brazilian highlands.

\section{Conclusion}

The results suggest that cane-pruning systems could be an alternative to increase production efficiency of Chardonnay in high-altitude region of southern Brazil.

For this trial site, good performances were observed for Cazenave and double Guyot training system.

\section{References}

[1] E. F. Gris. V.M. Burin. E. Brighenti. H. Vieira and M.T. Bordignon-Luiz. Phenology and ripening of Vitis vinifera L. grape varieties in São Joaquim. southern Brazil: a new South American wine growing region. Cie. Inv. Agr. 37, 61-75 (2010)

[2] L.I. Malinovski. L.J. Welter. A.F. Brighenti. H.J. Vieira. M.P. Guerra and A.L. Da Silva. 2012. Highlands of Santa Catarina/Brazil: a region with high potential for wine production. Acta Hort. 931, 433-440 (2012)

[3] A.F. Brighenti. E. Brighenti. V. Bonin. and L. Rufato. Caracterização fenológica e exigência térmica de diferentes variedades de uvas viníferas em São Joaquim. Santa Catarina - Brasil. Ciên. Rural. 43, 1162-1167 (2013)

[4] J.L. Marcon Filho. Sistemas de condução na produção de uvas viníferas e composição química e aromática de vinhos em região de altitude de Santa Catarina. (Thesis. Lages. 188. 2016)

[5] R. S. Jackson. Wine science: principles and application (4th ed. San Diego. Elsevier. 789. 2014) 
[6] E. Peterlunger. E. Celotti. G. Da Dalt. S. Stefanelli. G. Gollino and R. Zironi. Effect of training system on Pinot noir grape and wine composition. Am. J. Enol. Vitic. 53, 14-18 (2002)

[7] D. Ferree. T. Steiner. J. Gallander. D. Scurlock. G. Johns and R. Riesen. Performance of 'Seyval Blanc' Grape in Four Training Systems Over Five Years. Hortscince. 7, 1023-1027 (2002)

[8] Z. S. Beslic. S. R. Todic. V. V. Tesevic. M. B. Jadranin. M. M. Novakovic and D. Tesic. Pruning effect on content of quercetin and catechin in berry skins of cv. Blaufränkisch (Vitis vinifera L.) Turk J Agric For. 34, 461-466 (2010)

[9] L. F. Wessner and S. K. Kurtural. Pruning Systems and Canopy Management Practice Interact on the Yield and Fruit Composition of Syrah. Am. J. Enol. Vitic. 64, 134-138 (2013)

[10] T. Bates and J. Morris Mechanical Cane Pruning and Crop Adjustment Decreases Labor Costs and Maintains Fruit Quality in New York 'Concord' Grape Production. Horttechnology. 19, 247-253 (2009)

[11] J. M. Gambetta. S. E. P. Bastian. D. Cozzolino. and D. W. Jeffery. Factors Influencing the Aroma Composition of Chardonnay Wines J. Agric. Food Chem. 62, 6512-6534 (2014)
[12] P. Iland. P. Dry. T. Proffit and S. Tyerman. The Grapevine - From the Science to the Practice of Growing Vines for Wine (Wine Promotions: Adelaide. Australia. 2011)

[13] OIV - Organization Internationale de la Vigne et du Vin. Compendium of International Methods of Wine and Must Analysis (OIV. Paris. 2009)

[14] V.L. Singleton. J.A. Rossi. Colorymetry of total phenolics with phosphomolibdic-phosphotungstic acid reagent. Am. J. Enol. Vitic. 16, 144-158 (1965)

[15] G. S. Howell. Sustainable grape productivity and the growth-yield relationship: A review. Am. J. Enol. Vitic.. 52, 165-174 (2001)

[16] F. Bernizzoni. Long-term Performance of Barbera Grown under Different Training Systems and WithinRow Vine Spacings. Am. J. Enol. Vitic., 60, 339-348 (2009)

[17] D. Ferree, T. Steiner, J. Gallander, D. Scurlock, G. Johns, and R. Riesen. Performance of 'Seyval Blanc' Grape in Four Training Systems Over Five Years Hortscince, 7, 1023-1027 (2002)

[18] A.G. Reynolds and J.E. Vanden Heuvel. Influence of grapevine training systems on vine growth and fruit composition: A review. Am. J. Enol. Vitic. 60, 251-268 (2009) 